\title{
Effect of Firing Condition and Ingredients on the Swelling Behaviour of Iron Ore Pellets
}

\author{
T. SHARMA, R. C. GUPTA ${ }^{1)}$ and B. PRAKASH ${ }^{1)}$
}

Department of Fuel and Mineral Engineering, Indian School of Mines, Dhanbad - 826 004, India.

1) Department of Metallurgical Engineering, Institute of Technology, Banaras Hindu University, Varanasi - 221 005, India.

(Received on August 28, 1992; accepted in final form on January 22, 1993)

\begin{abstract}
In the present investigation an attempt has been made to determine the effect of firing temperature, firing time and ingredients/additives $\left(\mathrm{CaO}, \mathrm{MgO}, \mathrm{SiO}_{2}, \mathrm{Al}_{2} \mathrm{O}_{3}\right)$ on the swelling behaviour of iron ore pellets. For this purpose two Indian iron ore fines from Bailadila and Noamundi deposits and chemically pure iron oxide were used.

From the results obtained, it is observed that the swelling of iron ore pellet is controlled by the firing temperature, firing time and additives/ingredients present in the pellet. The growth of iron whisker is controlled by these ingredients. The presence of free lime promotes the swelling index of the pellet.
\end{abstract}

KEY WORDS: swelling; whisker growth; firing temperature; firing time; iron ore; pellet; crushing strength.

\section{Introduction}

It is well known that swelling of iron ore pellet is the outcome of the reduction process and is affected by all the parameters which govern the reduction behaviour of iron ore. ${ }^{1-14)}$ The chemical reaction, in general, is affected by temperature, time, nature of reducing gas, partial pressure and flowrate. The reduction behaviour also gets affected by initial condition of the iron ore to be reduced, particularly, chemical composition and porosity. Porosity plays a vital role in mass transfer during reduction. The porosity of lump ore is an inherent characteristic depending upon the nature of the ore deposit, whereas the porosity of iron ore pellet/briquette is dependent upon pelletization/briquetting parameters e.g., particle size distribution of the fines, rolling/ compaction pressure, firing temperature and firing time.

There are contradictory opinion about the effect of firing temperature on the swelling behaviour of iron ore pellets during reduction. Fuwa et al., ${ }^{1)}$ Vom Ende et al. ${ }^{4)}$ and others ${ }^{15-23)}$ have reported that with increase in firing temperature from 1000 to $1300^{\circ} \mathrm{C}$, the swelling index decreased, whereas Grance $^{2)}$ has reported increase in swelling index with increase in firing temperature from 1000 to $1300^{\circ} \mathrm{C}$. The difference in view may at least be understood in part by examining the composition of base material (iron ore). Vom Ende et al. ${ }^{4)}$ have concluded that in cases where lime was the major impurity causing whisker growth, the abnormal swelling decreased with increase in firing temperature.

Sasaki et al. ${ }^{23)}$ and Sharma et al. ${ }^{24)}$ have proposed that increase in firing temperature resulted in decreased porosity of the fired pellet and hence, due to increased strength of the pellet, the swelling index decreased. Sasaki et $a l^{23)}$ have also mentioned the formation of weak hematite bonds in pellets fired below $1100^{\circ} \mathrm{C}$. These bonds are stronger when firing is carried out at about $1200^{\circ} \mathrm{C}$ due to formation of slag which promotes the sintering rate of the pellet ${ }^{23,25,26)}$ and leads to formation of complex compound.

In the present investigation an attempt has been made to study the effect of firing temperature and time on the swelling behaviour of iron ore pellets. The experiments have been carried out using pure iron oxide and two natural iron ores obtained from Noamundi and Bailadila ore deposits having different gangue content. Attempt has also been made to quantify the effect of gangue content by varying $\mathrm{SiO}_{2}, \mathrm{Al}_{2} \mathrm{O}_{3}$ and $\mathrm{MgO}$ content of the pellet.

\section{Experimental Procedure}

In the present study high purity ferric oxide and two natural iron oxide ores from Bailadila and Noamundi Mines have been taken. The chemical analyses of these oxides are given in Table 1. These oxides were crushed and ground to $-150 \mu \mathrm{m}$. The size distribution of the raw material is shown in Table 2. Chemically pure alumina, silica, lime and magnesia were used as additive.

The three iron oxide fines were rolled on a Laboratory Model batch type Disc Pelletizer (at $20 \mathrm{rpm}$ ) to give 12 to $13 \mathrm{~mm}$ diameter pellet using $10-11 \%$ moisture. To adjust the chemical composition of the pellet various additives like $\mathrm{CaO}, \mathrm{MgO}, \mathrm{SiO}_{2}$ and $\mathrm{Al}_{2} \mathrm{O}_{3}$ powders were thoroughly mixed with the three oxides in different proportions. These pellets were fired at temperatures $1000,1100,1200,1300$ and $1350^{\circ} \mathrm{C}$ and soaked for different time interval ranging from 10 to $80 \mathrm{~min}$. The 
Table 1. Chemical analysis of iron oxides.

\begin{tabular}{clccccc}
\hline $\begin{array}{c}\text { Sl. } \\
\text { No. }\end{array}$ & Source & $\mathrm{Fe}$ & $\mathrm{SiO}_{2}$ & $\begin{array}{c}\mathrm{Al}_{2} \mathrm{O}_{3} \\
(\mathrm{wt} \%)\end{array}$ & $\mathrm{CaO}$ & Alkali \\
\hline 1 & Pure iron oxide & 69.9 & Trace & Trace & Trace & Nil \\
2 & Bailadila & 69.0 & 0.70 & 1.26 & Trace & Trace \\
3 & Noamundi & 64.0 & 2.0 & 3.60 & Trace & Trace \\
\hline
\end{tabular}

Table 2. Size distribution of iron oxides.

\begin{tabular}{lccc}
\hline \multirow{2}{*}{$\begin{array}{c}\text { Size } \\
(\mu \mathrm{m})\end{array}$} & \multicolumn{3}{c}{ Weight \% retained } \\
\cline { 2 - 4 } & Pure iron oxide & Bailadila ore & Noamundi ore \\
\hline$-150+106$ & 21.6 & 28.3 & 30.2 \\
$-106+75$ & 35.2 & 30.5 & 35.1 \\
-75 & 43.2 & 41.2 & 34.7 \\
\hline
\end{tabular}

heating rate of the pellet was $10^{\circ} \mathrm{C} / \mathrm{min}$ and the cooling rate was $50^{\circ} \mathrm{C} / \mathrm{min}$. The porosities of these pellets were measured before and after firing by mercury porosimeter and also by measuring density of the pellet. The fired pellets were stored in desiccators for swelling tests. The details of the apparatus and experimental procedure have been reported elsewhere. ${ }^{14,27,28)}$

The swelling index of the pellet during heating and at different fractions of reduction was measured by photographic method as reported elsewhere. ${ }^{27)}$ The swelling index was calculated as

$$
\text { Swelling index }=100\left(V_{a}-V_{i}\right) / V_{i}
$$

where, $V_{i}$ : initial volume of the pellet, and

$V_{a}:$ volume of the pellet after reduction for a given time.

Each test was repeated for 3 times and there was negligible difference among the results obtained. The degree of reduction of the pellet was calculated as

$$
\text { Degree of Reduction }=100\left(W_{i}-W_{a}\right) / W_{i}
$$

where, $W_{i}$ : weight of removable oxygen in the pellet, and

$W_{a}$ : weight of removable oxygen left in the pellet after reduction for a given time.

The reduction was carried out for $80 \mathrm{~min}$. When large cracks were developed, swelling index was measured by mercury displacement method. The crushing strength of the pellet was measured by universal testing machine and the structure of the reduced pellet was studied by scanning electron microscope. During the swelling tests the reduction parameters were fixed on the basis of previous studies. ${ }^{14,24,27,28)}$ These fixed parameters are as follows:
(1) Reducing gas:
$\mathrm{CO}$
(2) Flowrate:
$25 \mathrm{~cm}^{3} / \mathrm{s}$
(3) Partial pressure:
$1.0 \mathrm{~atm}$
(4) Reduction temperature: $1000^{\circ} \mathrm{C}$

\section{Results}

The pellets prepared from three different iron oxides, fired at $1000,1100,1200,1250,1300$ and $1350^{\circ} \mathrm{C}$ for $60 \mathrm{~min}$, were used for the swelling tests. The porosity of
Table 3. Effect of firing temperature on the porosity of Bailadila ore pellets. (Firing time: $60 \mathrm{~min}$ )

\begin{tabular}{cccc}
\hline \multirow{2}{*}{$\begin{array}{c}\text { Sl. } \\
\text { No. }\end{array}$} & $\begin{array}{c}\text { Firing temp. } \\
\left({ }^{\circ} \mathrm{C}\right)\end{array}$ & \multicolumn{2}{c}{ Porosity (vol\%) } \\
\cline { 3 - 4 } & & Before firing & After firing \\
\hline 1 & 1000 & 34 & 29 \\
2 & 1100 & 33 & 27 \\
3 & 1200 & 39 & 26 \\
4 & 1250 & 34 & 24 \\
5 & 1300 & 33 & 23 \\
6 & 1350 & 33 & 23 \\
\hline
\end{tabular}

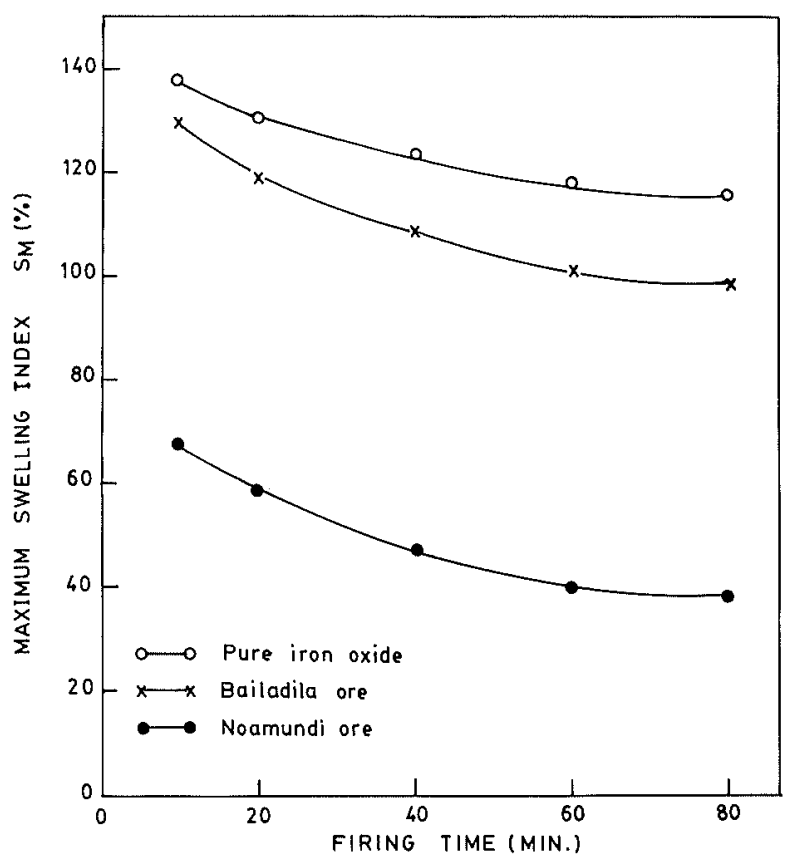

Fig. 1. Effect of firing temperature on maximum swelling index $\left(S_{M}\right)$ of pure iron oxide, Bailadila and Noamundi ore pellets. (Reducing gas: $\mathrm{CO}, P_{\mathrm{Co}}: 1 \mathrm{~atm}$, flowrate: 25 $\mathrm{cm}^{3} / \mathrm{s}$, reduction temp.: $1000^{\circ} \mathrm{C}$, firing time: $60 \mathrm{~min}$ ).

the Bailadila ore pellets before and after firing shown in Table 3, indicates that the porosity is decreased after firing. The porosity of the pellet decreases with increase in firing temperature from 1000 to $1350^{\circ} \mathrm{C}$. Similar results have been obtained for Noamundi and pure iron oxide pellets. The swelling values of these pellets are shown in Fig. 1, which reveal that the maximum swelling index $\left(S_{M}\right)$ is lowest for the pellets fired at highest temperature $\left(1350^{\circ} \mathrm{C}\right)$ and highest for the pellets fired at $1000^{\circ} \mathrm{C}$. The "maximum swelling" $\left(S_{M}\right)$ for Noamundi pellet (high gangue content, $5.6 \%$ ) fired at $1350^{\circ} \mathrm{C}$ is lowest $(28 \%)$ and highest $(100 \%)$ in pure iron oxide (without gangue) pellet. This observation indicates that firing temperature and gangue content both affect the swelling index of the pellet. These observations are in agreement with the results reported by Fuwa et al. ${ }^{1)}$ and others, ${ }^{4,15-23)}$ who have explained the sintering of particles as a cause for decrease in swelling index of the pellet.

To study the effect of firing time on the swelling index, the pellets were fired at $1250^{\circ} \mathrm{C}$ for different firing periods ranging from 10 to $80 \mathrm{~min}$. The porosity of the pellets, 
Table 4. Effect of firing time on the porosity of Bailadila ore pellets. (Firing temp.: $1250^{\circ} \mathrm{C}$ )

\begin{tabular}{cccc}
\hline \multirow{2}{*}{$\begin{array}{r}\text { Sl. } \\
\text { No. }\end{array}$} & $\begin{array}{c}\text { Firing time } \\
(\mathrm{min})\end{array}$ & \multicolumn{2}{c}{ Porosity (vol\%) } \\
\cline { 3 - 4 } & & Before firing & After firing \\
\hline 1 & 10 & 32 & 30 \\
2 & 20 & 34 & 29 \\
3 & 30 & 33 & 27 \\
4 & 40 & 33 & 25 \\
5 & 60 & 34 & 23 \\
6 & 80 & 33 & 22 \\
\hline
\end{tabular}

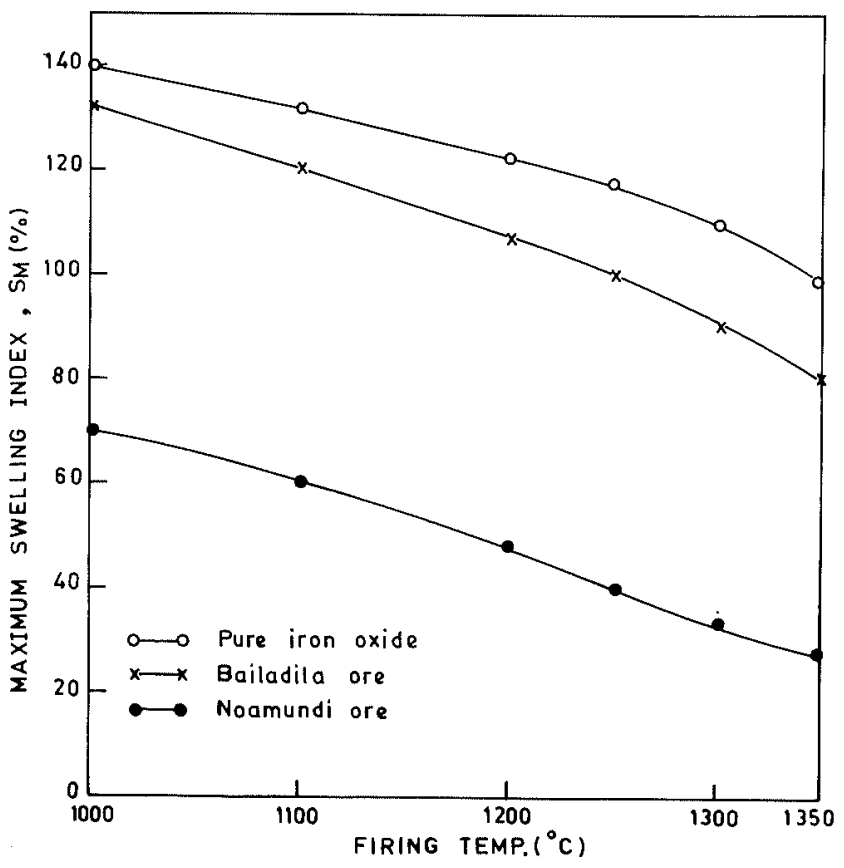

Fig. 2. Effect of firing time on maximum swelling index $\left(S_{M}\right)$ of pure iron oxide, Bailadila and Noamundi ore pellets. (Reducing gas: $\mathrm{Co}, P_{\mathrm{CO}}: \mathrm{I}$ atm, florate: $25 \mathrm{~cm}^{3} / \mathrm{s}$, reduction temp.: $1000^{\circ} \mathrm{C}$ firing temp.: $1250^{\circ} \mathrm{C}$ ).

thus obtained, are shown in Table 4 which indicates that with the increase in firing time from 10 to $80 \mathrm{~min}$, the porosity of Bailadila ore pellet decreased from about 33 to $22 \%$. Such change in porosity is true for all the three cases. Fired pellets having different porosities were subjected to the swelling test and the results obtained are shown in Fig. 2. It can be observed from this figure that the pellets fired for longer duration i.e., $80 \mathrm{~min}$ show less swelling than pellets fired for shorter duration. In this case also highest swelling index is observed in case of pure iron oxide pellet and lowest in case of Noamundi ore pellets. Similar observation has been reported by the authors ${ }^{27)}$ concluding that the presence of gangue decreases the swelling index of the pellet.

In order to know the difference in swelling index of the pellets made from three iron oxides, synthetic ore pellet of chemical composition corresponding to natural iron ore were made. For this purpose pure iron oxide; $\mathrm{Al}_{2} \mathrm{O}_{3}$ and $\mathrm{SiO}_{2}$ were mixed in the same proportion as Noamundi and Bailadila ore. These pellets were fired at different temperatures $\left(1000\right.$ to $1350^{\circ} \mathrm{C}$ ) for $60 \mathrm{~min}$. The values of maximum swelling obtained are shown in Table
Table 5. Effect of firing temperature on the maximum swelling index $\left(S_{M}\right)$ of synthetic ore pellets. (Firing time: $60 \mathrm{~min}$, reduction temp.: $1000^{\circ} \mathrm{C}$, reducing gas: $\mathrm{CO}$, partial pressure: $1 \mathrm{~atm}$, flowrate: $25 \mathrm{~cm}^{3} / \mathrm{s}$ )

\begin{tabular}{|c|c|c|c|}
\hline \multirow{2}{*}{$\begin{array}{l}\text { Sl. } \\
\text { No. }\end{array}$} & \multirow{2}{*}{$\begin{array}{l}\text { Firing temp. } \\
\qquad\left({ }^{\circ} \mathrm{C}\right)\end{array}$} & \multicolumn{2}{|c|}{$\begin{array}{l}\text { Maximum swelling index } S_{M}(\%) \\
\text { of synthetic ore corresponding to }\end{array}$} \\
\hline & & Bailadila ore & Noamundi ore \\
\hline 1 & 1000 & 138 & 115 \\
\hline 2 & 1100 & 128 & 100 \\
\hline 3 & 1200 & 117 & 80 \\
\hline 4 & 1250 & 102 & 40 \\
\hline 5 & 1300 & 90 & 35 \\
\hline 6 & I 350 & 82 & 29 \\
\hline
\end{tabular}

Table 6. Effect of firing time on the maximum swelling index $\left(S_{M}\right)$ of synthetic ore pellets. (Firing temp.: $1250^{\circ} \mathrm{C}$ reduction temp.: $1000^{\circ} \mathrm{C}$, reducing gas: $\mathrm{CO}$, partial pressure $1 \mathrm{~atm}$, flowrate: $25 \mathrm{~cm}^{3} / \mathrm{s}$ )

\begin{tabular}{|c|c|c|c|}
\hline \multirow{2}{*}{$\begin{array}{l}\text { Sl. } \\
\text { No. }\end{array}$} & \multirow{2}{*}{$\begin{array}{l}\text { Firing time } \\
\quad(\min )\end{array}$} & \multicolumn{2}{|c|}{$\begin{array}{l}\text { Maximum swelling index } S_{M}(\%) \\
\text { of synthetic ore corresponding to }\end{array}$} \\
\hline & & Bailadila ore & Noamundi ore \\
\hline 1 & 10 & 135 & 80 \\
\hline 2 & 20 & 124 & 65 \\
\hline 3 & 40 & 115 & 50 \\
\hline 4 & 60 & 102 & 40 \\
\hline 5 & 80 & 100 & 39 \\
\hline
\end{tabular}

Table 7. Effect of firing temperature on the maximum swelling index of lime containing pellet. (Reduction temp.: $1000^{\circ} \mathrm{C}$, firing time: $60 \mathrm{~min}$, lime addition: $2 \%$, reducing gas: $\mathrm{CO}$, partial pressure: $1 \mathrm{~atm}$, flowrate: $25 \mathrm{~cm}^{3} / \mathrm{s}$ )

\begin{tabular}{lcc}
\hline \multirow{2}{*}{ Pellet } & \multicolumn{2}{c}{$\begin{array}{c}\text { Maximum swelling index } S_{M}(\%) \\
\text { of pellet fired at }\end{array}$} \\
\cline { 2 - 3 } & $1250^{\circ} \mathrm{C}$ & $1000^{\circ} \mathrm{C}$ \\
\hline Pure iron oxide & 98 & 245 \\
Bailadila ore & 79 & 212 \\
Noamundi ore & 19 & 138 \\
\hline
\end{tabular}

5. From this table, it is observed that synthetic pellets fired at $1350^{\circ} \mathrm{C}$ show almost equal swelling values to the natural ore pellets. But the pellets fired below $1250^{\circ} \mathrm{C}$ show higher swelling values. This indicates that the increase in gangue content is not only sufficient to control the swelling index of the pellet but higher firing temperature is also required.

In order to ensure the effect of firing time, synthetic pellets were fired for different time $(10$ to $30 \mathrm{~min})$ at $1250^{\circ} \mathrm{C}$ and the results of swelling are shown in Table 6. From these results it is observed that sufficient time and higher temperature are required for firing of the synthetic pellet in order to decrease the swelling index of the pellet.

The effect of individual ingredient and additives was studied by adding reagent grade silica, alumina, lime and magnesia in different proportion to the pure iron oxide and the two natural iron ores. These pellets were fired 
Table 8. Effect of additives on the maximum swelling index $\left(S_{M}\right)$ of iron oxide pellets. (Firing temp: $1250^{\circ} \mathrm{C}$, firing time: $60 \mathrm{~min}$ )

\begin{tabular}{|c|c|c|c|c|c|}
\hline \multirow{2}{*}{$\begin{array}{l}\text { Sl. } \\
\text { No. }\end{array}$} & & \multirow{2}{*}{$\begin{array}{l}\text { Additive } \\
(w t \%)\end{array}$} & \multicolumn{3}{|c|}{ Maximum swelling index $S_{M}(\%)$} \\
\hline & & & $\begin{array}{l}\text { Pure iron } \\
\text { oxide }\end{array}$ & $\begin{array}{c}\text { Bailadila } \\
\text { ore }\end{array}$ & $\begin{array}{c}\text { Noamundi } \\
\text { ore }\end{array}$ \\
\hline 1 & & Nil & 118 & 100 & 40 \\
\hline \multirow[t]{4}{*}{2} & $\mathrm{SiO}_{2}$ & 2 & 94 & 76 & 21 \\
\hline & & 4 & 70 & 56 & 10 \\
\hline & & 6 & 40 & 32 & 4 \\
\hline & & 8 & 20 & 16 & 1 \\
\hline \multirow[t]{4}{*}{3} & $\mathrm{Al}_{2} \mathrm{O}_{3}$ & 2 & 107 & 89 & 32 \\
\hline & & 4 & 96 & 80 & 21 \\
\hline & & 6 & 88 & 70 & 16 \\
\hline & & 8 & 75 & 61 & 12 \\
\hline \multirow[t]{4}{*}{4} & $\mathrm{MgO}$ & 2 & 93 & 75 & 19 \\
\hline & & 4 & 68 & 54 & 9 \\
\hline & & 6 & 39 & 30 & 4 \\
\hline & & 8 & 19 & 14 & 1 \\
\hline \multirow[t]{4}{*}{5} & $\mathrm{CaO}$ & 2 & 98 & 79 & 19 \\
\hline & & 4 & 72 & 57 & 12 \\
\hline & & 6 & 43 & 34 & 5 \\
\hline & & 8 & 23 & 18 & 2 \\
\hline
\end{tabular}

at 1000 and $1250^{\circ} \mathrm{C}$ for $60 \mathrm{~min}$ and the fired pellets were reduced under the condition adopted in this study. There was not much change in swelling index of the pellets fired at $1000^{\circ} \mathrm{C}$ when $2 \% \mathrm{MgO}, \mathrm{SiO}_{2}$ and $\mathrm{Al}_{2} \mathrm{O}_{3}$ was used as additives. But there was drastic increase in swelling index of the pellet containing lime. The results obtained are shown in Table 7.

When the pellets fired at $1250^{\circ} \mathrm{C}$ for $60 \mathrm{~min}$ were subjected to swelling test, decrease in swelling index was obtained. The results obtained are shown in Table 8, where maximum swelling $\left(S_{M}\right)$ has been shown against the percentage of additives $\left(\mathrm{CaO}, \mathrm{MgO}, \mathrm{SiO}_{2}\right.$ and $\left.\mathrm{Al}_{2} \mathrm{O}_{3}\right)$.

From this table, it is observed that by addition of 2 4, 6 and $8 \% \mathrm{SiO}_{2}, \mathrm{CaO}$ and $\mathrm{MgO}$ the ' $S_{M}$ ' value is significantly decreased and the swelling index comes down to normal range. But addition of $\mathrm{Al}_{2} \mathrm{O}_{3}$ is comparatively less effective in decreasing the swelling index of the pellet. Addition of $8 \%$ alumina to pure iron oxide, Bailadila and Noamundi ore pellets decreases the swelling from 118 to $75 \%, 100$ to $61 \%$ and 40 to $12 \%$ respectively.

\section{Discussion}

Swelling index of iron ore pellet includes thermal expansion, phase transformation and growth of iron whiskers. Thermal expansion and volume change during phase transformation are inherent properties of the ore. The volume increase due to these factors are in the normal range of swelling whereas volume change due to growth of iron whisker is in the range of abnormal swelling and leads to disintegration of the pellet. In order to minimise swelling the growth of iron whiskers should be restricted. The growth of iron whiskers is restricted
Table 9. Effect of additives on the crushing strength of fired pellet.

\begin{tabular}{|c|c|c|c|c|c|}
\hline \multirow{2}{*}{$\begin{array}{l}\text { S1. } \\
\text { No. }\end{array}$} & & \multirow{2}{*}{$\begin{array}{l}\text { Additives } \\
\text { (wt } \%)\end{array}$} & \multicolumn{3}{|c|}{ Crushing strength ( $\mathrm{kg} ; 12 \mathrm{~mm}$ dia. pellet) } \\
\hline & & & $\begin{array}{c}\text { Pure iron } \\
\text { oxide }\end{array}$ & $\begin{array}{c}\text { Bailadila } \\
\text { ore }\end{array}$ & $\begin{array}{l}\text { Noamundi } \\
\text { ore }\end{array}$ \\
\hline 1 & & Nil & 210 & 222 & 230 \\
\hline \multirow[t]{4}{*}{2} & $\mathrm{SiO}_{2}$ & 2 & 225 & 240 & 245 \\
\hline & & 4 & 235 & 249 & 251 \\
\hline & & 6 & 248 & 256 & 258 \\
\hline & & 8 & 263 & 270 & 275 \\
\hline \multirow[t]{4}{*}{3} & $\mathrm{Al}_{2} \mathrm{O}_{3}$ & 2 & 212 & 223 & 231 \\
\hline & & 4 & 215 & 225 & 232 \\
\hline & & 6 & 218 & 227 & 234 \\
\hline & & 8 & 221 & 230 & 236 \\
\hline \multirow[t]{4}{*}{4} & $\mathrm{CaO}$ & 2 & 220 & 238 & 245 \\
\hline & & 4 & 228 & 249 & 252 \\
\hline & & 6 & 242 & 260 & 260 \\
\hline & & 8 & 250 & 269 & 268 \\
\hline \multirow[t]{4}{*}{5} & $\mathrm{MgO}$ & 2 & 228 & 240 & 250 \\
\hline & & 4 & 239 & 250 & 265 \\
\hline & & 6 & 256 & 259 & 273 \\
\hline & & 8 & 270 & 275 & 280 \\
\hline
\end{tabular}

by increasing the gangue content ${ }^{1,2,27)}$ and decreasing the porosity. ${ }^{28)}$ Due to difference in gangue content highest swelling index is obtained in pure iron oxide pellet and lowest in Noamundi pellet. ${ }^{27)}$ Restriction in growth of iron whisker has been reported in the pellets containing higher gangue. ${ }^{27)}$ It is observed from Tables 3 and 4 that there is decrease in porosity of the pellet with increase in the firing temperature and time. It has been well established that lower porosity results into restricted whisker growth and hence, lower swelling index of the pellet. ${ }^{28)}$ This is the reason for lower swelling index of the pellets fired at higher temperature for longer time.

Silica is the most common constituent in the iron ore and generally, it is considered as an unwanted constituent. High silica content leads to the formation of fayalite and glassy or crystalline silicate which have a lower melting temperature around $1050-1200^{\circ} \mathrm{C}$. The presence of this fused layer of glassy silicate in the pellet structure decreases the swelling index of the pellet by restricting the growth of iron whiskers. The observation is supported by the scanning electron micrograph shown in Fig. 3(a) which reveals that with the increase in silica content, the size and number of whisker decrease and with $8 \%$ silica addition to pure iron oxide a spongy mass of reduced iron appeared. The crushing strength of the pellet is also increased with addition of silica (Table 9). This increased strength does not allow the whiskers to grow and hence, lower swelling is obtained.

Alumina is a refractory constituent and its solubility in iron is limited (Atlas et al. $^{29)}$ and Maun et al. ${ }^{30)}$ ). In presence of other ingredients like $\mathrm{CaO}$, and $\mathrm{SiO}_{2}$, it forms compounds, like $\mathrm{CaO} \cdot \mathrm{Al}_{2} \mathrm{O}_{3} \cdot 2 \mathrm{Fe}_{2} \mathrm{O}_{3}$ or $4 \mathrm{CaO} \cdot \mathrm{Al}_{2} \mathrm{O}_{3}$. $\mathrm{Fe}_{2} \mathrm{O}_{3}$, after firing above $1200-1250^{\circ} \mathrm{C}$ (Harbord et al. ${ }^{31 \text { ) }}$ and Mazanek et al. ${ }^{32)}$ ). These compounds are formed by 


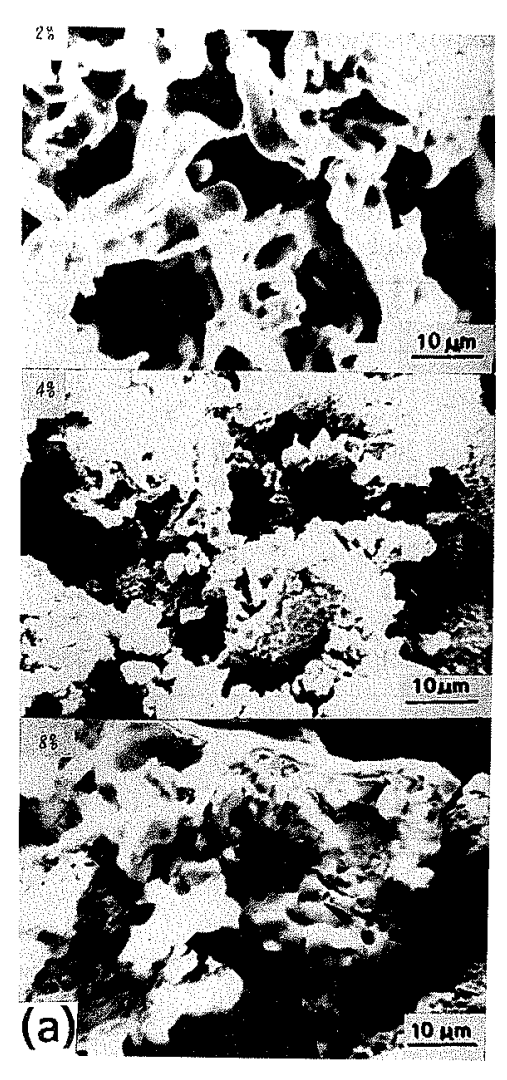

$\mathrm{SiO}_{2}$

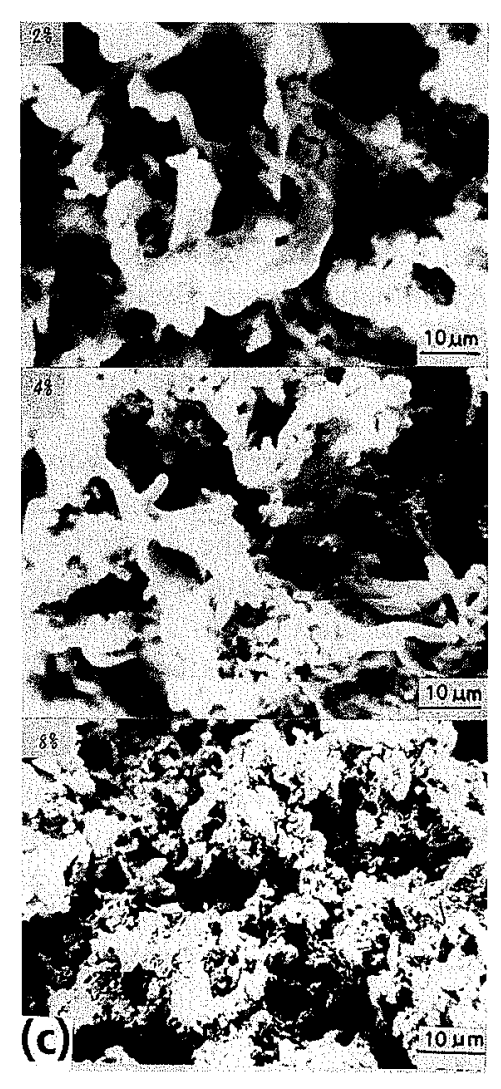

$\mathrm{MgO}$

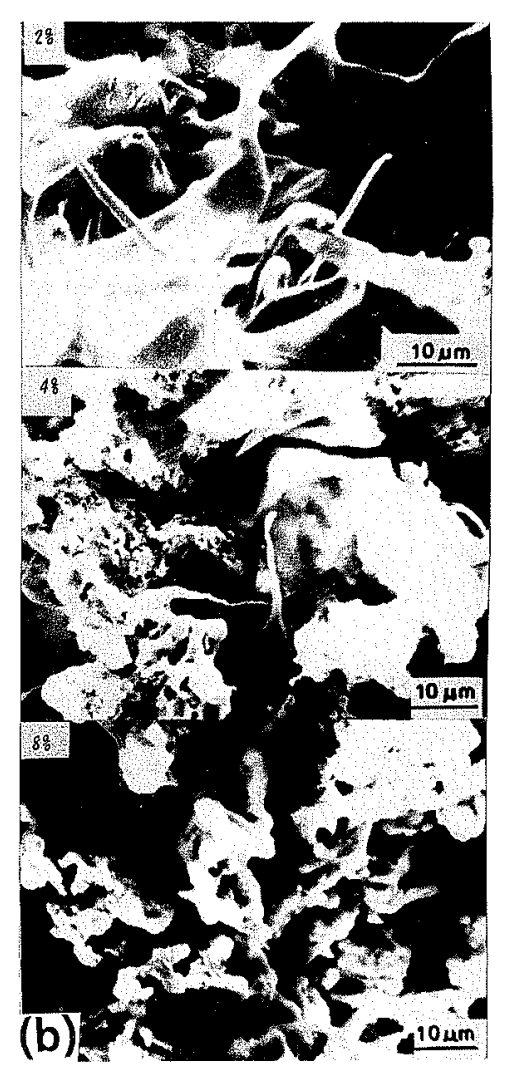

$\mathrm{Al}_{2} \mathrm{O}_{3}$

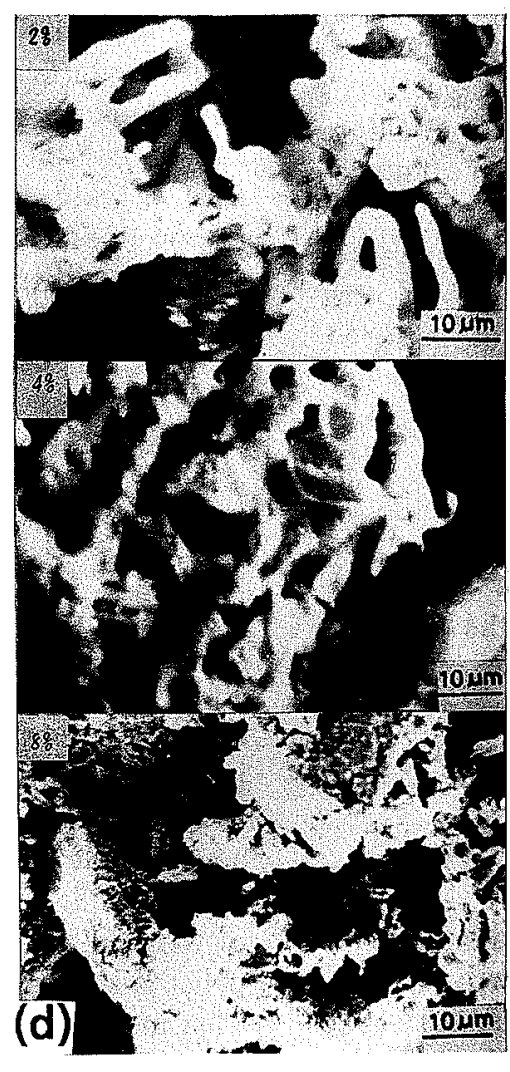

$\mathrm{CaO}$
Fig. 3.

Scanning electron micrograph of pure iron oxide pellet containing, $\mathrm{CaO}, \mathrm{MgO}, \mathrm{SiO}_{2}$ and $\mathrm{Al}_{2} \mathrm{O}_{3}$ reduced at $1000^{\circ} \mathrm{C}$ with $\mathrm{CO}$ flowing at the rate of $25 \mathrm{~cm}^{3} / \mathrm{s}$. ( $P_{\mathrm{co}}: 1 \mathrm{~atm}$, firing time: $60 \mathrm{~min}$, firing temp.: $\left.1250^{\circ} \mathrm{C}\right)$ solid state reaction, the rate of their formation being very slow. Due to this reason alumina present in the slag is not effective in controlling the growth of whiskers which can be seen from Fig. 3(b). This figure reveals that even after addition of $8 \% \mathrm{Al}_{2} \mathrm{O}_{3}$ to pure iron oxide there is not remarkable decrease in size and number of the 
whiskers. This may be due to availability of dry iron oxide surface and higher softening point of alumina. Due to this reason alumina is not able to increase the strength of the pellet significantly (Table 9). A small decrease in nucleation and growth of whiskers may be due to the physical presence of solid alumina particles.

Though, magnesia is a highly refractory oxide and it forms high melting compounds with other oxides e.g., $\mathrm{MgO} \cdot \mathrm{Al}_{2} \mathrm{O}_{3}$ (m.p. $2135^{\circ} \mathrm{C}$ ), $\mathrm{MgO} \cdot \mathrm{Fe}_{2} \mathrm{O}_{3}$ (m.p. $1415^{\circ} \mathrm{C}$ ) etc., but, by solid state reaction, the formation of solid solution of $\mathrm{Fe}_{2} \mathrm{O}_{3}$ in $\mathrm{MgO}$ starts about at $1000^{\circ} \mathrm{C}$ and considerable amount of $\mathrm{MgO} \cdot \mathrm{Fe}_{2} \mathrm{O}_{3}$ is formed around $1200-1300^{\circ} \mathrm{C}\left(\right.$ Chester $\left.^{33)}\right)$. Mazanek and Jasienska ${ }^{34)}$ have reported formation of ferro-monticellite and monticellite. Hase-nack ${ }^{35)}$ and others ${ }^{36-40)}$ have reported the formation of magnesio-ferrite in magnesia containing pellet which increases the bonding strength of the pellet resulting into decreased swelling. The observations of the present investigation regarding effect of magnesia are in agreement with those of other workers (Grance, ${ }^{2)}$ Hasenack $^{35)}$ and others ${ }^{41-44)}$ ), who have reported decrease in swelling index may be due to the formation of above mentioned compound during firing of the pellet. These compounds seem to restrict the nucleation and growth of iron whiskers during reduction by enveloping iron oxide particles and whiskers. Due to this reason, the decrease in number and size of the whiskers with increase in magnesia content of pellet has been observed in the scanning electron micrograph shown in Fig. 3(c). It is most effective in increasing the crushing strength of the pellet (Table 9).

The melting point of calcium ferrite and silicate containing lime is in the range of $1160-1180^{\circ} \mathrm{C}$ and formation of calcium ferrite starts even at $950-1000^{\circ} \mathrm{C}$. But the rate of formation of calcium ferrite at 950$1000^{\circ} \mathrm{C}$ is very slow ${ }^{45)}$ and it increases with the increase in temperature. In the range 1050 to $1200^{\circ} \mathrm{C}$, a part of hematite in contact with lime forms a limited amount of monocalcium ferrite $\left(\mathrm{CaO} \cdot \mathrm{Fe}_{2} \mathrm{O}_{3}\right)$ and with high percentage of lime, dicalcium ferrite $\left(2 \mathrm{CaO} \cdot \mathrm{Fe}_{2} \mathrm{O}_{3}\right)$ is formed. ${ }^{34)}$ In presence of silica a limited amount of calcium silicate is formed at $1200^{\circ} \mathrm{C}$ and upto this temperature some amount of free lime has been reported. ${ }^{26)}$ Above $1200^{\circ} \mathrm{C}$, there is formation of $\mathrm{CaO}$. $\mathrm{Fe}_{2} \mathrm{O}_{3}, \mathrm{CaO} \cdot 2 \mathrm{Fe}_{2} \mathrm{O}_{3}$ and $2 \mathrm{CaO} \cdot \mathrm{SiO}_{2}\left(\mathrm{Matsuno}^{25)}\right.$ ) and when basicity is around 2 , the formation of calcium ferrite and calcium silicate takes place. In this case, it appears that lime, which increases the total gangue content and also brings down the melting point of slag phases formed during firing, restricts the nucleation and growth of iron whiskers by enveloping the iron oxide surface. These observations are in agreement with the available literature $^{15,46-50)}$ where swelling index has been reported to decrease in the presence of combined lime. These observations have been further supported by the scanning electron micrograph of iron oxide pellet containing 2, 4 and $8 \%$ lime, shown in Fig. 3(d).

When firing temperature was $1000^{\circ} \mathrm{C}$, the presence of lime promoted the swelling index of the pellet. Nicolle and $\mathrm{Rist}^{51)}$ have proposed that when lime is present in free form it causes lattice distortion because of larger diameter of $\mathrm{Ca}^{2+}(0.99 \AA)$ than $\mathrm{Fe}^{2+}(0.75 \AA)$. The distortion of wustite lattice promote whisker growth in two ways: they help the storage of large amount of iron and provide surface defects for nucleation. ${ }^{51)}$ In case of free $\mathrm{MgO}$, there is not drastic change in swelling index, though both the constituents are basic in nature. Nicolle and Rist $^{51)}$ have studied the effect of $\mathrm{MgO}$ addition in wustite and they have proposed the $\mathrm{Mg}^{2+}$ ion is slightly smaller $(0.66 \AA)$ than the $\mathrm{Fe}^{2+}$ ion $(0.75 \AA)$ and hence, it does not cause lattice distortion therefore, whisker growth is not promoted. This is the reason for lower swelling index in case of free $\mathrm{MgO}$ pellets. If the lime containing pellets are fired at higher temperature for sufficient time formation of calcium ferrite takes place. The presence of calcium ferrite act as a trap for lime which is no longer available to contaminate wustite. ${ }^{51)}$ Hence, whisker growth is restricted and lower swelling is observed.

The formation of different compounds and bonds depends upon the composition of the pellet, firing temperature and time. The strength of the pellets is controlled by the above parameters. The porosity of the fired pellet is also controlled by these parameters. The crushing strength of the pellet after addition of $4 \%$ silica, alumina, lime and magnesia to pure iron oxide pellets fired at different temperature for $60 \mathrm{~min}$ is plotted in Fig. 4. The figure shows that with increase in firing temperature the crushing strength of the pellet is increased. Among the four ingredients, $\mathrm{MgO}$ has been found to be the most effective in increasing the crushing strength of the pellet whereas alumina is the least effective. Lime and silica added pellets fall in the intermediate range i.e., between magnesia and alumina. Silica is more effective than lime in increasing the crushing strength of the pellet. Similar results have been obtained when the pellets containing $4 \%$ silica, lime, magnesia

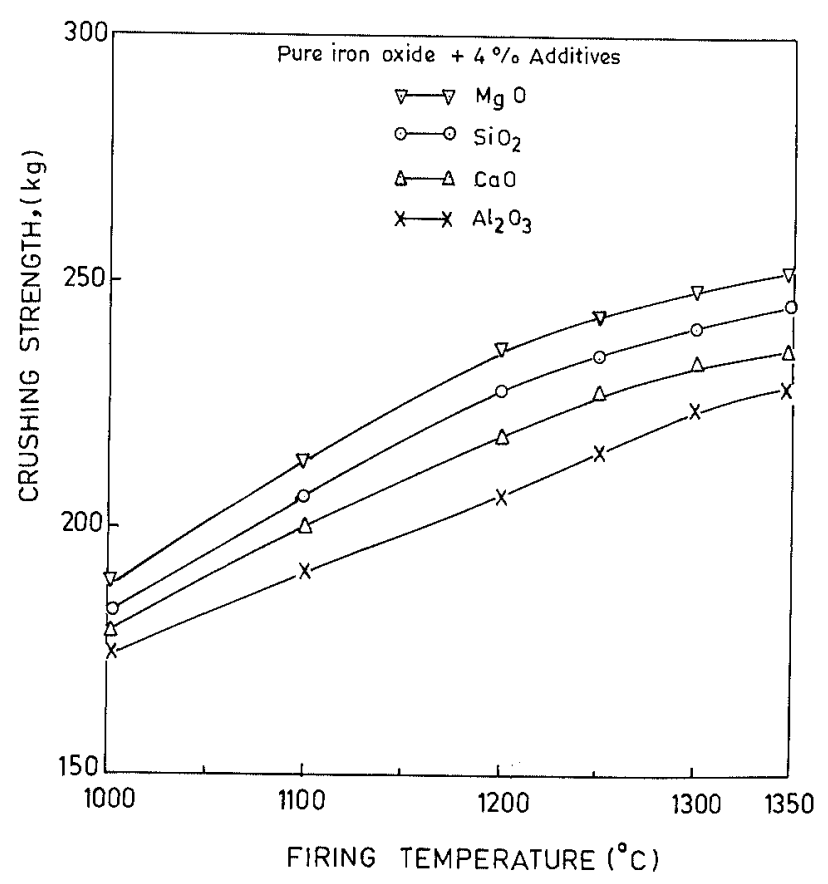

Fig. 4. Effect of firing temperature on the crushing strength of pure iron oxide pellet containing $4 \% \mathrm{SiO}_{2}, \mathrm{CaO}$, $\mathrm{MgO}$ and $\mathrm{Al}_{2} \mathrm{O}_{3}$. (Firing time: $60 \mathrm{~min}$ ). 


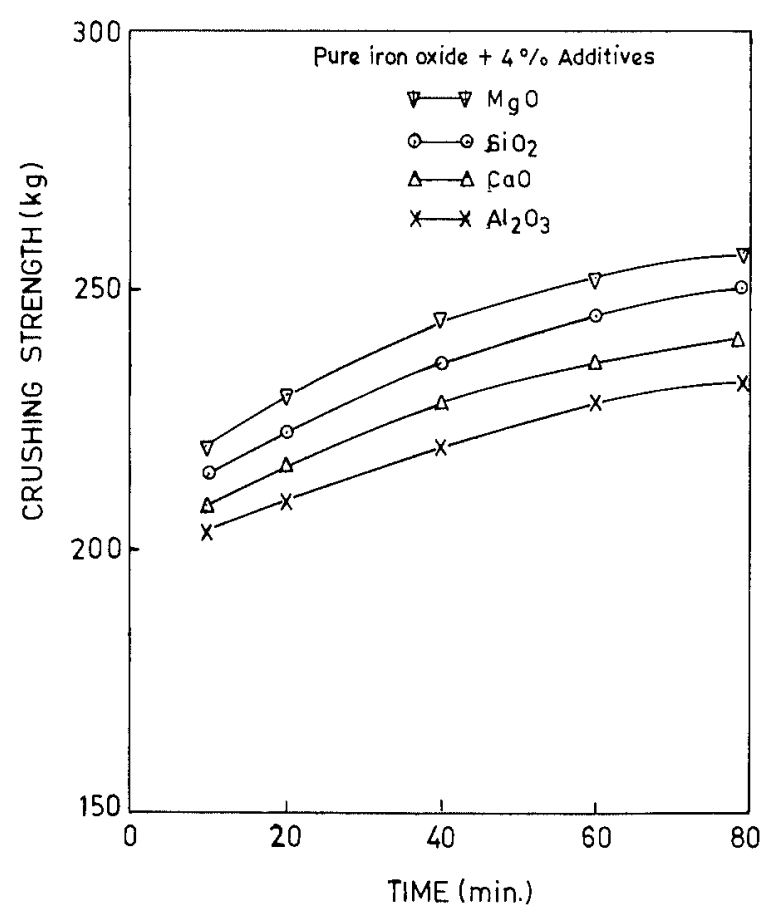

Fig. 5. Effect of firing time on the crushing strength of pure iron oxide pellet containing $4 \% \mathrm{CaO}, \mathrm{MgO}, \mathrm{SiO}_{2}$ and $\mathrm{Al}_{2} \mathrm{O}_{3}$. (Firing temp.: $1350^{\circ} \mathrm{C}$ ).

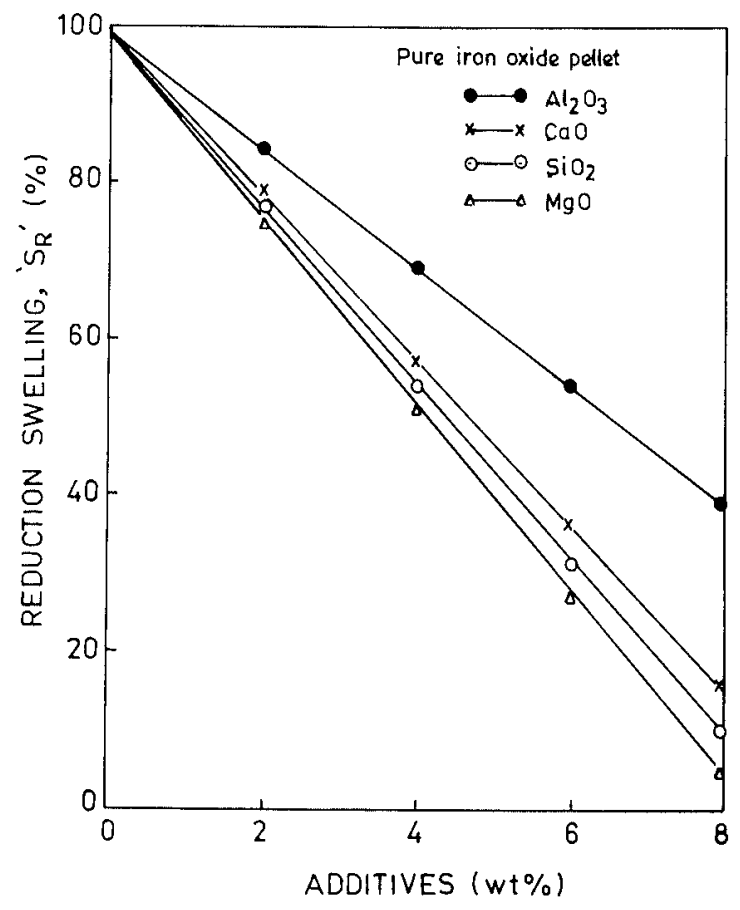

Fig. 6. Effect of additives on the reduction swelling ' $S_{R}$ ' of pure iron oxide pellet fired at $1250^{\circ} \mathrm{C}$ for $60 \mathrm{~min}$. (Reduction temp.: $1000^{\circ} \mathrm{C}$, reducing gas: $\mathrm{CO}, P_{\mathrm{Co}}$ : $1 \mathrm{~atm}$, flowrate: $25 \mathrm{~cm}^{3} / \mathrm{s}$ ).

and alumina fired at $1350^{\circ} \mathrm{C}$ for different time interval (10 to $80 \mathrm{~min}$ ). The results are plotted in Fig. 5. In view of the above discussion, it can be said that if an additive is able to form a fusible slag and also increase the bonding strength of the pellet, it can decrease the swelling index of iron ore pellets effectively. The swelling seems to be directly related to the quantity of ingredient present in the pellet. "Reduction Swelling" $\left(S_{R}\right)$ maintains linear relationship with percent addition of $\mathrm{CaO}, \mathrm{MgO}, \mathrm{SiO}_{2}$ and $\mathrm{Al}_{2} \mathrm{O}_{3}$ to pure iron oxide pellet (Fig. 6) as per equation

$$
S_{R}=a X+b
$$

where $S_{R}$ is the value of swelling obtained during reduction only and is defined by equation

$$
S_{M}=S_{R}+S_{T}
$$

where, $S_{M}$ : maximum swelling of the pellet including thermal expansion and swelling due to reduction, and

$S_{T}$ : thermal swelling (volume change during heating of the pellet because of thermal expansion and allotropic transformation).

Equation (4) has been discussed and graphically shown by the author. ${ }^{27)}$ The value of ' $a$ ' for silica, alumina, lime and magnesia are $-11.25,-5.15,-10.5$ and -11.5 respectively and the value of ' $b$ ' is 99 which is the "Reduction Swelling" $\left(S_{R}\right)$ for pure iron oxide pellet without any additive.

The equation for individual ingredients are

$$
\begin{aligned}
& S_{R}=-11.25\left(X_{1}\right)+99 \\
& S_{R}=-5.15\left(X_{2}\right)+99 \ldots \\
& S_{R}=-10.5\left(X_{3}\right)+99 \ldots \\
& S_{R}=-11.5\left(X_{4}\right)+99 \ldots
\end{aligned}
$$

where $X_{1}, X_{2}, X_{3}$ and $X_{4}$ are weight $\%$ of $\mathrm{SiO}_{2}, \mathrm{Al}_{2} \mathrm{O}_{3}$, $\mathrm{CaO}$ and $\mathrm{MgO}$, respectively.

From the present investigation and the observations of various other workers, it seems that the swelling index of pellet is dependent upon the growth of iron whiskers during reduction which is very much dependent upon the rate of reduction, ${ }^{14)}$ number of nucleation sites ${ }^{51)}$ and strength of the pellet. These whiskers have been observed to grow on wustite surface, in pores, at the edges and corners, either originally present in the pellet or created during reduction as reported by Kahtany et $a l .{ }^{52)}$ When bonding strength of the pellet is less and porosity is high, these whiskers push and adjacent ore grains of iron or other oxides and hence, result into increase in volume and sometime, cracking and disintegration of pellets. But when bonding strength is higher, either due to stronger bridging of iron oxides or due to presence of slag bonds, these whiskers are not able to push the adjacent surface mechanically and in that case lower swelling is observed.

\section{Conclusions}

On the basis of results obtained during the investigation the following conclusions have been drawn:

(1) Firing temperature and time play an important role in controlling the maximum swelling index of the pellet. The porosity of the pellet decreases with increase in firing temperature and time.

(2) Maximum swelling index of the pellet decreases with increase in the gangue content of the pellet. Synthetic pellets with higher firing temperature and time have shown lower value of maximum swelling index. 
(3) Additives like $\mathrm{CaO}, \mathrm{MgO}$ and $\mathrm{SiO}_{2}$ play important role in decreasing the maximum swelling index of the pellet provided firing temperature is around $1250^{\circ} \mathrm{C}$ and firing time is around $60 \mathrm{~min} . \mathrm{Al}_{2} \mathrm{O}_{3}$ is not effective in decreasing the maximum swelling index.

(4) Presence of free or uncombined lime promotes the maximum swelling index of the pellet.

\section{REFERENCES}

1) T. Fuwa and S. Ban-Ya: Trans. Iron Steel Inst. Jpn., 9 (1969), 137.

2) L. Grance: Proc. ICSTIS Tokyo, Suppl. Trans. Iron Steel Inst. Jpn., 11 (1971), 45.

3) S. Taniguchi, et al.: Trans. Iron Steel Inst. Jpn., 18 (1978), 633.

4) H. Vom Ende, et al.: Stahl Eisen, 91 (1971), 815.

5) S. Taniguchi and M. Ohmi: Trans. Jpn. Inst. Met., 21 (1980), 433.

6) S. Taniguchi and M. Ohmi: Trans. Jpn. Inst. Met., 19 (1978), 581.

7) S. Taniguchi and M. Ohmi: Trans. Iron Steel Inst. Jpn., 20 (1980), 433.

8) J. K. Wright: Trans. Iron Steel Inst. Jpn., 17 (1977), 726.

9) G. Thaning: Ironmaking Steelmaking, 3 (1976), 57.

10) T. Y. Malysheva, et al.: Steel USSR, 2 (1972), 418

11) I. Shigaki, et al:: Trans. Iron Steel Inst. Jpn., 22 (1982), 838.

12) A. N. Spector and A. N. Pyrikov: Steel USSR, 2 (1974), 4

13) S. Taniguchi, et al.: Trans. Iron and Steel Inst. Jpn., 20 (1980), 753.

14) T. Sharma, et al.: ISIJ Int., 32 (1992), 812

15) H. A. Kortmann: Trans. Soc. Min. Eng. AIME, 254 (1973), 184.

16) S. Watanabe and M. Yoshinaga: Tetsu-to-Hagané, 51 (1965), 583.

17) S. Watanabe and M. Yoshinaga: Trans. Soc. Min. Eng. AIME, 241 (1968), 1.

18) H. E. N. Stone and B. L. Daniell: Trans. Soc. Min. Eng. AIME, 244 (1969), 251.

19) N. Pongish: Ironmaking Proc., Vol. 26, (1967), 146.

20) V. W. Wenzel and H. W. Gudenau: Stahl Eisen, 90 (1970), 689.

21) M. C. Chang: Blast Furnace Steel Plant, 55 (1967), 1019.
22) H. Brill-Edwards, et al.: Journal ISI, 207 (1961), 1565.

23) M. Sasaki, et al.: Trans. Iron Steel Inst. Jpn., 8 (1968), 146.

24) T. Sharma, et al.: ISIJ Int., 32 (1992), 1268.

25) F. Matsuno: Trans. Iron Steel Inst. Jpn., 19 (1979), 595.

26) J. T. Filton and D. C. Goldering: Journal ISI, 204 (1966), 452.

27) T. Sharma, et al.: Miner. Eng., 3 (1990), 509.

28) T. Sharna, et al.: ISIJ Int., 31 (1991), 312.

29) L. M. Atlas and W. K. Sumida: J. Am. Ceram. Soc., 41 (1958), 150.

30) A. Maun and C. L. Gee: J. Am. Ceram. Soc., 39 (1956), 207.

31) N. H. Harbord and D. C. Goldring: Journal ISI, 203 (1965), 349.

32) E. Mazanek and S. Jasienska: Journal ISI, 202 (1964), 319.

33) J. H. Chesters: Refractories-Production and Properties, Iron Steel Inst., London, (1973).

34) E. Mazanek and S. Jasienska: Journal ISI, 201 (1963), 60.

35) N. A. Hasenack: Trans. Soc. Min. Eng. AIME, 260 (1976), 263.

36) O. Tsuchiya, et al:: Tetsu-to-Hagané, 66 (1980), 1930.

37) T. Sugiyama, et al.: Trans. Iron Steel Inst. Jpn., 20 (1980), B 421.

38) K. Narita, et al.: Trans. Iron Steel Inst. Jpn., 19 (1979), 766.

39) A. E. Paladino: J. Am. Ceram. Soc., 43 (1960), 183.

40) K. Narita, et al.: Tetsu-to-Hagané, 66 (1980), 326.

$41)$ O. Tsuchiya, et al:: Tetsu-to-Hagané, 66 (1980), 1840.

42) G. G. Effimenco: Steel USSR, 2 (1972), 335.

43) J. C. Nigano: Trans. Soc. Min. Eng. AIME, 254 (1973), 328.

44) A. Das and U. N. Mishra: Trans. Indian Inst. Met., 33 (1980), 230.

45) K. P. Hass, et al:: Proc. B. F. Coke Oven Raw Mat. Conf. AIME, (1960), 429.

46) M. Sasaki and T. Nakajawa: Trans. Iron Steel Inst. Jpn., 10 (1970), 464.

47) M. Tigerschiold: Journal ISI, 177 (1954), 13

48) O. Tsuchiya: Tetsu-to-Hagané, 66 (1980), 1297.

49) Y. Iguchi and M. Inouye: Trans. Iron Steel Inst. Jpn., 22 (1982), 678.

50) M. Asada et al.: Trans. Iron Steel. Inst. Jpn., 8 (1968), 245.

51) N. B. Carter et al:: Ironmaking Steelmaking, 10 (1983), 243.

52) M. M. Al. Kahtany and Y. K. Rao: Ironmaking Steelmaking, 7 (1980), 49. 